\title{
Crossing Experiments Detect Genetic Incompatibility among Populations of Triatoma brasiliensis Neiva, 1911 (Heteroptera, Reduviidae, Triatominae)
}

\author{
Jane Costa $/ * /+$, Carlos Eduardo Almeida/**, Jean Pierre Dujardin***, \\ Charles Benjamin Beard****
}

\begin{abstract}
Núcleo de Informatização, Coleção Entomológica, Departamento de Entomologia, Instituto Oswaldo Cruz-Fiocruz, Av. Brasil 4365, 21045-900 Rio de Janeiro, RJ, Brasil *EID, APHL ****Entomology Branch, Division of Parasitic Disease, CDC, Atlanta, GA, US **Núcleo Avançado de Estudos de Vetores e Artrópodes Peçonhentos, Museu de Ciências, UBM, Barra Mansa, RJ, Brasil ***Institute de Recherches pour le Développement, Paris, France
\end{abstract}

Triatoma brasiliensis is composed of at least four geographic populations (brasiliensis, melanica, macromelasoma, and juazeiro) that have distinct chromatic, morphologic, biologic and ecologic patterns, and genetic composition. Reciprocal crosses between all pairwise combinations were carried out in order to evaluate the genetic and reproductive compatibility of these four populations. The F1 individuals developed normally and the resulting adults were crossed again to test the F2 and F3 viability. Genetic incompatibility was found between melanica and brasiliensis populations.

Key words: Triatoma brasiliensis - populations - genetic incompatibility

Triatoma brasiliensis Neiva, 1911, the main Chagas disease vector in Brazil, (Silveira \& Vinhaes 1999, Costa et al. 2003a) presents great chromatic variation, which has lead in the past to the description of two subspecies: $T$. brasiliensis melanica Neiva \& Lent, 1941 and $T$. brasiliensis macromelasoma Galvão, 1956. These subspecies were synonymized as $T$. brasiliensis due to the allegation that intermediate forms could be found in the natural environment (Lent \& Wygodzinsky 1979). The nominal subspecies and those of differentiated darker patterns (once described as subspecies) are here referred to as populations and called brasiliensis, melanica and macromelasoma. During the field collections carried out in several sites including the type localities, a fourth chromatic pattern was collected in Juazeiro (State of Bahia) and it will be referred to as the juazeiro population (Costa 1997, Costa et al. 1997a)

Recently, in an effort to clarify the evolutionary relationship of these distinct populations of Triatoma brasiliensis sensu lato, several approaches have been

Supported by National Health Foundation, Association of Public Health Laboratories and Centers for Disease Control and Prevention, Oak Ridge Institute for Science and Education, Supporting Program to Strategic Research in Health-Papes III, and the State of Rio de Janeiro Research Foundation.

Presented in the International Symposium on the Advances in Knowledge of Chagas Disease 90 Years After its Discovery.

${ }^{+}$Corresponding author. Fax: +55-21-2573.4468. E-mail: zgq6@cdc.gov and jcosta@gene.dbbm.fiocruz.br

Received 12 November 2002

Accepted 8 April 2003 carried out: morphologic (Costa et al. 1997a), bionomic (Costa \& Marchon-Silva 1998), ecologic (Costa et al. 1998, 2002), and molecular (Costa et al. 1997b, 2001). It was shown that $T$. brasiliensis is composed of at least four distinct geographic populations, and a great level of differentiation was observed among them. The genetic distances generated by isoenzymes and the mitochondrial DNA sequences revealed levels of divergence higher than those usually obtained in comparison between other closely related triatomine species (Costa et al. 1997b, 2001).

In order to evaluate the genetic and reproductive compatibility of these four T. brasiliensis populations, reciprocal crossing experiments among all possible combinations were conducted, and observed through the production of F3 eggs, according to recommendations to evaluate genetic compatibilities (Mayr 1963). The experimentation was conducted under laboratorial conditions of temperature $\left(X=29.10^{\circ} \mathrm{C}, \min .22\right.$, and $\left.\max .31\right)$, and humidity $(X=71.8 \%$, min. 31 , and max. 50). Fifth instar nymphs from colonies originated from individuals collected $(n>30)$ in the type localities (Caicó, Rio Grande do Norte brasiliensis; Petrolina, Pernambuco - macromelasoma; Espinosa, Minas Gerais - melanica; and Juazeiro, Bahia juazeiro) were isolated and kept individually until adulthood. Reciprocal crosses between all pairwise combinations were carried out, totaling 12 possible combinations. Three couples of each combination were formed and kept separately in plastic flasks $(10 \times 10 \times 16 \mathrm{~cm})$ containing folded filter paper. Intra population crosses were also performed for control, totaling 12 couples. All of these couples were maintained simultaneously and fed until repletion on mice once a month. All couples, experimental and control, produced viable eggs with variable percentages of 
eclosion (70-90\%). Nymphs presented normal development to adulthood. No morphologic anomaly was observed in any of the nymphal instars (Table I). Subsequently, virgin F1 hybrid adults were crossed to test for the viability of the F2. Three couples generated by each of the previous combinations were formed. The same procedure was also utilized to assess the viability of the F3 eggs. All the hybrid couples were able to produce viable F2 and F3 eggs, with the exception of the combination of brasiliensis male $\times$ melanica female. In this combination a high mortality of the F2 fifth instar nymphs (80\%) was observed. Only two females and two males reached adulthood (Table I). Of the other six nymphs, three died as fifth instars following ecdysis, two failed to reach adulthood and died after one year being fed monthly, and one presented incomplete ecdysis to adulthood and died. Two hundred and eleven $\mathrm{F} 3$ eggs were obtained from these two couples with $0 \%$ of eclosion.

The heterogeneity among combinations shown in Table I was highly significant $\left(\mathrm{P}_{\mathrm{X} 2}<0.0001\right)$, indicating unequal reproductive performance among the pairs. The average numbers of adults obtained from the six intergroup crossings (Table I) were used as an indicator of reproductive performance (Table II) to allow a characterization of populations based on the criterion of interfertility. This was illustrated by an UPGMA dendrogram (Sokal \& Michener 1958) showing putative genetic compatibilities (Figure). Its topology suggested the brasiliensismacromelasoma as the closest pair and melanica as the more external group, a pattern already obtained elsewhere from genetic data (Costa et al. 1997b, 2001).

The present study showed that in spite of the morphologic, biologic, ecologic, and molecular differences previously demonstrated among these four $T$. brasiliensis
TABLE II

Average numbers of obtained adults from crosses between four populations of Triatoma brasiliensis: brasiliensis (bras), melanica (mel), macromelasoma (macr) and juazeiro (juaz).

Each cell contains an average from twelve crosses: the three F1 and three F2 crosses between groups plus the corresponding reciprocal crosses (see Table I). Values in diagonal are average numbers of adults obtained from within population crosses, six ones instead of twelve (see Table I)

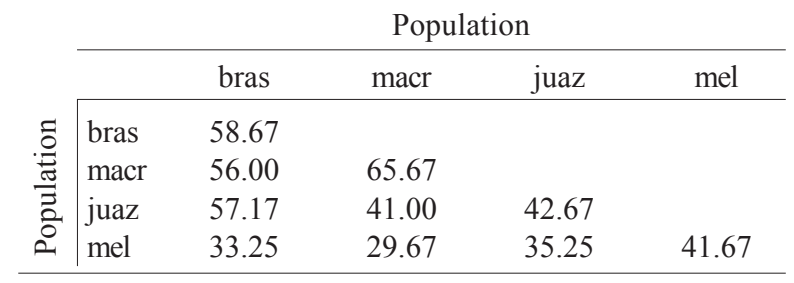
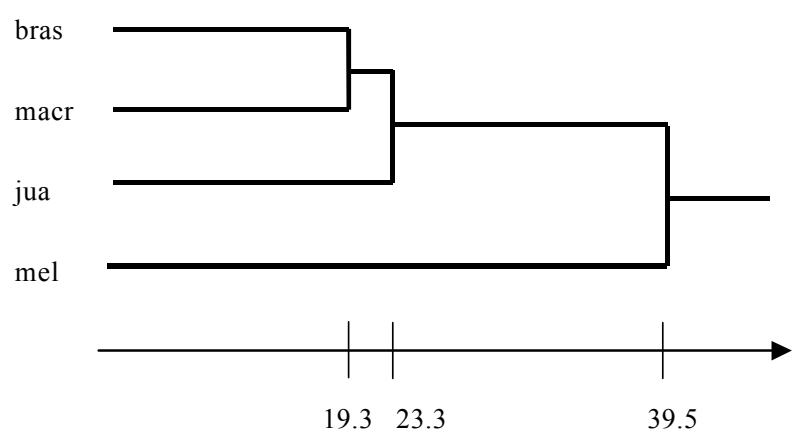

A tree illustration of relative reproductive compatibility among populations of Triatoma brasiliensis: brasiliensis (bras), melanica (mel), macromelasoma (macr), and juazeiro (juaz) using the average distance method (UPGMA). The values of Table II were used as parameters describing each population; the UPGMA algorithm used the Euclidian formula to compute differences.

TABLE I

Number of adults obtained from each of the three couples (parentals and hybrids F1) formed for the crossing experiments carried out between four populations of Triatoma brasiliensis: brasiliensis (bras), melanica (mel), macromelasoma (macr) and juazeiro (juaz)

\begin{tabular}{|c|c|c|c|c|c|c|c|c|}
\hline Parentals & F1 & F1 & $\mathrm{F} 1$ & Subtotals & $\mathrm{F} 2$ & $\mathrm{~F} 2$ & $\mathrm{~F} 2$ & Subtotals \\
\hline \multicolumn{9}{|c|}{ Inter-group crossings } \\
\hline bras $\sigma^{\star} \times$ mel $\uparrow$ & 67 & 65 & 0 & 132 & 2 & 2 & 0 & 4 \\
\hline bras $9 \times$ mel $o^{x}$ & 51 & 55 & 61 & 167 & 25 & 32 & 39 & 96 \\
\hline bras $o^{\top} \times$ macr i & 126 & 55 & 0 & 181 & 87 & 80 & 10 & 177 \\
\hline bras $+\times$ macr $o^{*}$ & 54 & 74 & 0 & 128 & 107 & 0 & 79 & 186 \\
\hline bras $o^{\top} \times$ juaz +9 & 14 & 62 & 119 & 195 & 48 & 68 & 60 & 176 \\
\hline bras $9 \times$ juaz $o^{\star}$ & 66 & 86 & 76 & 228 & 57 & 7 & 23 & 87 \\
\hline mel $o^{\top} \times$ macr +9 & 20 & 105 & 0 & 125 & 21 & 26 & 32 & 79 \\
\hline mel $+\times$ macr $o^{*}$ & 42 & 52 & 0 & 94 & 30 & 8 & 20 & 58 \\
\hline mel $\sigma^{\top} \times$ juaz ㅇ & 98 & 32 & 60 & 190 & 0 & 15 & 31 & 46 \\
\hline mel $+\times$ juaz $o^{x}$ & 13 & 68 & 0 & 81 & 55 & 36 & 15 & 106 \\
\hline macr $o^{*} \times$ juaz o & 22 & 20 & 18 & 60 & 92 & 0 & 79 & 171 \\
\hline $\operatorname{macr}+\times$ juaz $o^{*}$ & 4 & 55 & 149 & 208 & 42 & 0 & 11 & 53 \\
\hline \multicolumn{9}{|l|}{ Control crossings } \\
\hline bras $\times$ bras & 27 & 83 & 74 & 184 & 45 & 69 & 54 & 168 \\
\hline $\mathrm{mel} \times \mathrm{mel}$ & 51 & 69 & 0 & 120 & 42 & 43 & 45 & 130 \\
\hline macr $\times$ macr & 72 & 55 & 80 & 207 & 60 & 70 & 57 & 187 \\
\hline juaz × juaz & 63 & 60 & 40 & 163 & 57 & 36 & 0 & 93 \\
\hline
\end{tabular}


populations, they were able to freely interbreed and to produce viable progeny in the laboratory. Interestingly, the two populations (melanica and brasiliensis) known to present the lowest genetic identity values, based on either alloenzyme data or mitochondrial DNA sequences (Costa et al. 1997b, 2001), or the highest ecologic distinctiveness (Costa et al. 2002), also revealed the lowest reproductive compatibility, disclosing sterility in $\mathrm{F} 2$ crosses.

According to Ryckman (1962) the reproductive isolation is the best criteria to assess the taxonomic status of a determined "population". In this regard, the present data suggest that brasiliensis and melanica populations are in the beginning of a true speciation process. Our data also indicate that despite their high genetic heterogeneity, the four differentiated populations of $T$. brasiliensis are still reproductively compatible. However, reproductive compatibility is not proof of conspecificity. Actually, many examples exist of possible hybridization among well established species of Triatominae (Usinger et al. 1966, Perlowagora-Szumlewics \& Correia 1972). Due to the apparent "gradient" in the likely speciation process among the T. brasiliensis populations, and the well-known possibility of hybridization among many species of Triatominae (Usinger et al. 1966), the taxonomic status of these four distinct T. brasiliensis "populations", at least of one of them (melanica), should be reconsidered at specific level. We are preparing this revision in the lights of the present and previous studies on this complex (Costa et al. 2003b).

Under the perspective of vector control, the present results, as well as the previous ecologic and molecular approaches, showed that the distinct allopatric and parapatric "populations" of T. brasiliensis lato sensu could be treated as individual targets. From an epidemiologic point-of-view, it was also important to stress that these "populations" are not simply morphologic variants of the same biologic entity, which could explain why they have different epidemiologic importance (Costa et al. 1998, 2003a), and why they are not expected to behave as a single species in response to any environmental change.

\section{ACKNOWLEDGEMENTS}

To Fernando Monteiro for the critical reading and suggestions.

\section{REFERENCES}

Costa J 1997. Triatoma brasiliensis Neiva, 1911 (Hemiptera, Reduviidae, Triatominae): Estudos Morfológicos, Biológicos e Isoenzimáticos sobre Diferentes Padrões Cromáticos, $\mathrm{PhD}$ Thesis, Instituto Oswaldo Cruz-Fiocruz, Rio de Janeiro, $100 \mathrm{pp}$.

Costa J, Marchon-Silva V 1998. Período de intermuda e resistência ao jejum de diferentes populações de Triatoma brasiliensis (Hemiptera, Reduviidae, Triatominae). Entomol Vect 5: 23-34.

Costa J, Almeida JR, Britto C, Duarte R, Marchon-Silva V,
Pacheco R 1998. Ecotopes, natural infection and trophic resources of Triatoma brasiliensis (Hemiptera, Reduviidae, Triatominae). Mem Inst Oswaldo Cruz 93: 7-13.

Costa J, Almeida CE, Dotson E, Lins A, Vinhaes M, Silveira AC, Beard CB 2003a. The epidemiologic importance of Triatoma brasiliensis as a Chagas disease vector in Brazil: a revision of domiciliary captures during 1933-1999. Mem Inst Oswaldo Cruz 98: 443-449.

Costa J, Barth OM, Marchon-Silva, Almeida CE, Freitas-Sibajev MG, Panzera F 1997a. Morphological studies on the Triatoma brasiliensis Neiva, 1911 (Hemiptera, Reduviidae, Triatominae) - Genital structures and eggs of different chromatic forms. Mem Inst Oswaldo Cruz 92: 493-498.

Costa J, Freitas-Sibajev MG, Marchon-Silva V, Pires MQ, Pacheco R 1997b. Isoenzymes detect variation in populations of Triatoma brasiliensis (Hemiptera-ReduviidaeTriatominae). Mem Inst Oswaldo Cruz 92: 459-464.

Costa J, Monteiro F, Beard CB 2001. Triatoma brasiliensis Neiva, 1911 the most important Chagas disease vector in Brazil Phylogenetic and population analyzes correlated to epidemiologic importance. Am J Trop Med Hygiene 65: 280.

Costa J, Monteiro F, Dujardin JP, Beard CB 2003b. The brasiliensis complex. Infection, Genetics and Evolution 85 : (in press).

Costa J, Townsend P, Beard CB 2002. Ecological niche modeling and differentiation of populations of Triatoma brasiliensis Neiva, 1911, the most important Chagas disease vector in Northeastern Brazil. Am J Trop Med Hygiene 67: 516-520.

Galvão AB 1956. Triatoma brasiliensis macromelasoma $\mathrm{n}$. subsp. (Reduviidae, Hemiptera). Rev Bras Malariol Doen Trop 7: 455-457.

Lent H, Wygodzinsky P 1979. Revision of Triatominae (Hemiptera, Reduviidae) and their significance as vectors of Chagas' disease. Bull Am Mus Nat History 163: 125-520.

Mayr E 1963. Populações, Espécies e Evolução, Ed. Nacional, Univ. São Paulo, ed. 1977, São Paulo, 485 pp.

Neiva A 1911. Contribuição para o estudo dos hematophagos brazileiros e descrição de uma nova espécie de Triatoma. Brazil-Médico 25: 461-462.

Neiva A, Lent H 1941. Sinopse dos triatomineos. Rev Entomol 12: 62-92.

Perlowagora-Szumlewics A, Correia MV 1972. Induction of male sterility manipulation of genetic mechanisms present in vector species of Chagas disease (remarks on integrating sterile-male release with insecticidal control measures against vectors of Chagas disease). Rev Inst Med Trop São Paulo 14: 360-371.

Ryckman R 1962. Biosystematics and hosts of the Triatoma protracta complex in North America. Univ California Publ Ent 27: 93-239.

Silveira AC, Vinhaes MC 1999. Elimination of vector-borne transmission of Chagas disease. Mem Inst Oswaldo Cruz 94 (Suppl. I): 405-411.

Sokal RR, Michener CD 1958. A statistical method for evaluating systematic relationships. Univ Kansas Sci Bull 28: 14091438 .

Usinger RL, Wygodzinsky P, Ryckman RE 1966. The biossistematics of Triatominae. Ann Rev Entomol 11: 309330 . 